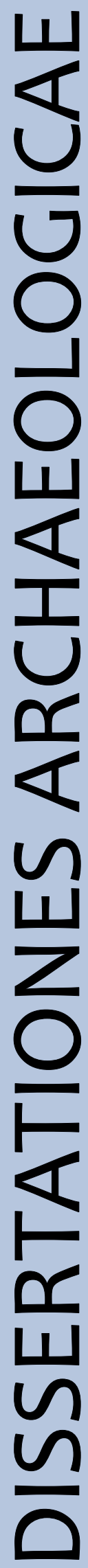

ex Instituto Archaeologico Universitatis de Rolando Eötvös nominatae
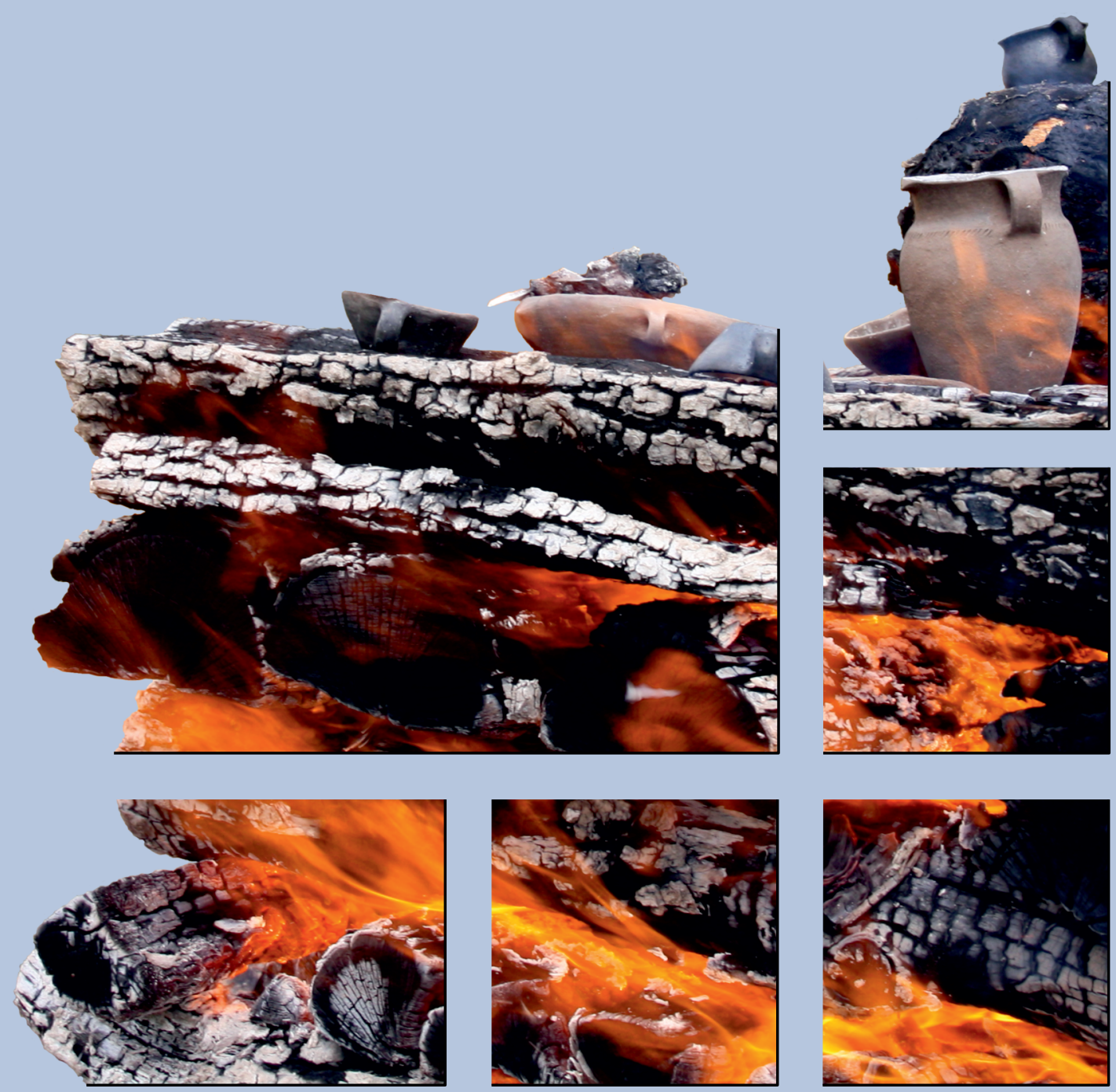

$$
\text { Ser。 3. No } 0_{0} \sigma_{0} \mid 2018
$$




\section{Dissertationes Archaeologicae ex Instituto Archaeologico}

Universitatis de Rolando Eötvös nominatae Ser. 3. No. 6.

Budapest 2018 


\section{Dissertationes Archaeologicae ex Instituto Archaeologico}

Universitatis de Rolando Eötvös nominatae Ser. 3. No. 6.

Editor-in-chief:

DÁvid BARTUS

Editorial board:

LÁsZló BARTOSIEWICZ

LÁSZLÓ BORHY

ZOLTÁN CZAJLIK

ISTVÁN FELD

GÁBOR KALLA

PÁL RACZKY

MiKLÓS SZABÓ

Tivadar Vida

Technical editor:

GÁBOR VÁcZI

Proofreading:

ZsófIA KondÉ

SzILVIA BARTUS-SzÖLLősI

Aviable online at http://dissarch.elte.hu

Contact: dissarch@btk.elte.hu

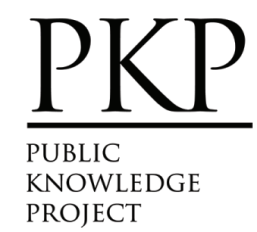

๑ E Eötvös Loránd University, Institute of Archaeological Sciences

Layout and cover design: Gábor Váczi

Budapest 2018 


\section{CONTENTS}

Zsolt Mester

In memoriam facques Tixier (1925-2018)

\section{ARTICLES}

Katalin SEBőK

On the possibilities of interpreting Neolithic pottery - Az újkökori kerámia értelmezési lehetőségeiről

András FüZESI - Pál RACZKY

Öcsöd-Kováshalom. Potscape of a Late Neolithic site in the Tisza region

Katalin SEBőK - Norbert FARAgó

Theory into practice: basic connections and stylistic affiliations of the Late Neolithic settlement at Pusztataskony-Ledence 1

Eszter Solnay

Early Copper Age Graves from Polgár-Nagy-Kasziba

László GuCsi - Nóra Szabó

Examination and possible interpretations of a Middle Bronze Age structured deposition

Kristóf FÜLÖP

Why is it so rare and random to find pyre sites? Two cremation experiments to understand the characteristics of pyre sites and their investigational possibilities

Gábor János TARBAY

"Looted Warriors" from Eastern Europe

Péter MogYoRós

Pre-Scythian burial in Tiszakürt

Szilvia JoHÁczi

A New Method in the Attribution? Attempts of the Employment of Geometric Morphometrics in the Attribution of Late Archaic Attic Lekythoi 
The Roman aqueduct of Brigetio

Lajos JuHÁsz

A republican plated denarius from Aquincum

Barbara HAJDU

Terra sigillata from the territory of the civil town of Brigetio

Krisztina HoppÁL - István VIDA - Shinatria AdHityatAma - Lu Yahui 461

'All that glitters is not Roman'. Roman coins discovered in East Java, Indonesia.

A study on new data with an overview on other coins discovered beyond India

\section{FIELD REPORTS}

Zsolt MESTER - Ferenc CSERPÁK - Norbert FARAGÓ

Preliminary report on the excavation at Andornaktálya-Marinka in 2018

Kristóf FÜLÖP - Denisa M. LÖNHARDT - Nóra SZABÓ - Gábor VÁcZI

Preliminary report on the excavation of the site Tiszakürt-Zsilke-tanya

Bence Simon - Szilvia JohÁcZI - Zita KIS

Short report on a rescue excavation of a prehistoric and Árpádian Age site near Tura

(Pest County, Hungary)

Zoltán CzAJlik - Katalin NovinszKi-Groma - László RupNIK - András BöDőcs - et al. 527

Archaeological investigations on the Süttö plateau in 2018

Dávid BARTus - László BORHY - Szilvia JoHÁczi - Emese SzÁMADó

Short report on the excavations in the legionary fortress of Brigetio (2017-2018)

Bence Simon - Szilvia JoháczI

Short report on the rescue excavations in the Roman Age Barbaricum near Abony

(Pest County, Hungary)

Szabolcs Balázs NAGY

Recent excavations at the medieval castle of Bánd 


\section{Thesis Abstracts}

Rita JENEY

Lost Collection from a Lost River: Interpreting Sir Aurel Stein's "Sarasvatī Tour" in the History of South Asian Archaeology

István VIDA

The Chronology of the Marcomannic-Sarmatian wars. The Danubian wars of Marcus Aurelius in the light of numismatics

Zsófia MASEK

Settlement History of the Middle Tisza Region in the $4^{\text {th }}-6^{\text {th }}$ centuries AD.

According to the Evaluation of the Material from Rákóczifalva-Bagi-földek 5-8-8A sites

Alpár Doвоs

Transformations of the human communities in the eastern part of the Carpathian Basin between the middle of the $5^{\text {th }}$ and $7^{\text {th }}$ century. Row-grave cemeteries in Transylvania, Partium and Banat 


\title{
Recent excavations at the medieval castle of Bánd
}

\author{
SZABOLCs BALÁZs NAGY \\ Institute of Archaeological Sciences \\ Eötvös Loránd University \\ n.szabolcsbalazs@gmail.com
}

\begin{abstract}
After the first minor investigations between 1997 and 2007 a new series of excavations have been conducted at the medieval castle of Band in 2013, 2017 and 2018. ${ }^{1}$ Although the scale of the latest works is still quite moderate compared to the dimensions of the fortification, the observations resulted not only in considerable amounts of find material but also in objects that raised important issues and unexpected questions. The archaeological evidence proves a special relationship between the castle and the medieval settlement(s) of Bánd, the details of which definitely call for further research.
\end{abstract}

At first sight the medieval castle called Essegvár (literally Esseg Castle) may seem a rather insignificant fortification (Fig. 1). Bánd village is located in Western Hungary (Transdanubia) at the foot of the Eastern Bakony Mountains, only ca. 12 kilometres from the medieval seat of the royal county and episcopal see of Veszprém, not far from the northern shores of Lake Balaton. On the top of the 30 meter high castle hill only humble remains of the Essegvár Castle survived: two square towers incorporated in the largely demolished castle wall, as well as an impressive ditch delimiting the fortification from the southern and eastern slopes of the hill (Figs 2-3).

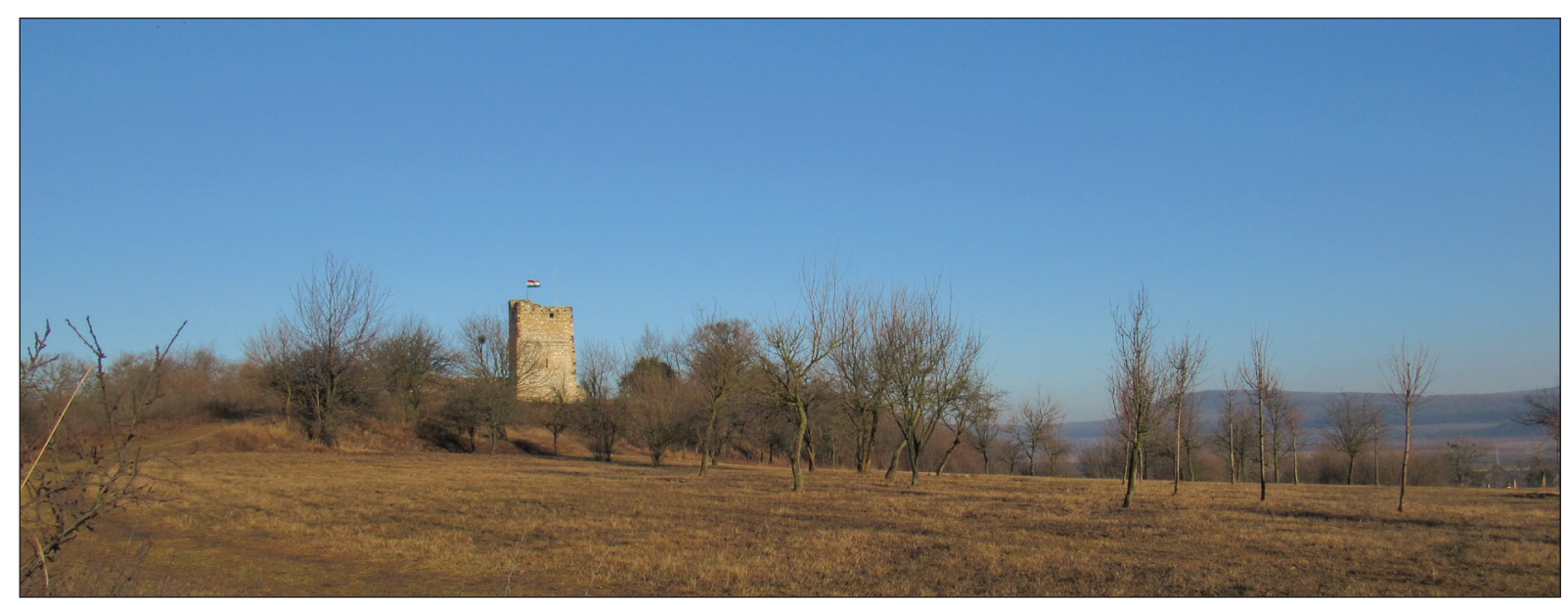

Fig. 1. The castle hill from the southeast (Photo: F. Erdősi).

1 The excavations between 2013 and 2018 have been conducted in cooperation between the Eötvös Loránd University and the Laczkó Dezső Museum, supported by the Council of Bánd Municipality and the National Cultural Fund of Hungary. The prime mover of the works was a local inhabitant Ferenc Erdősi. I am indebted to him and all the participants, students and volunteers who joined the research. Students from the university were: Marcell Barcsi, Piroska Derzsi, Olivér Gillich, Ádám Horváth, Mátyás Jánosi, Bence Jőrösi, Márk Kékesi, Boglárka Kertész, Gizella Kovács, Franciska Simon, Lili Sólyom, Gergely Szoboszlay, László Vig. I am also grateful to Pál Rainer and István Feld for their advices and remarks. 


\section{Written evidence}

The first mention of the site - referred to as "Seg sive Band", i.e. Seg or Band - is known from 1233 when its lands were owned by the Igmánd clan. From the records we hear about "Castrum Scegh" only in 1309. This year the fortification and its appurtenances (i.e. the estates attached to it) were handed over to Lőrinte magister and his sons from the Lörinte clan by Lőrinte's cousin Nicholas magister from the Igmánd clan. According to the written evidence, the first half of the fourteenth century was marked by several violent acts of Lörinte and his heirs mainly against the properties and tenants of the bishop and chapter of Veszprém. The confiscated goods and hostages were usually taken to the castle that could provide shelter for the possessions, the lords and their retinue as well. Lőrinte and his sons most probably used the castle as their de facto residence. A charter of 1334 already mentions Lőrinte's son as Thomas Segvári, which family name has later got firm in two forms both referring to the castle: Segvári and Essegvári. ${ }^{2}$

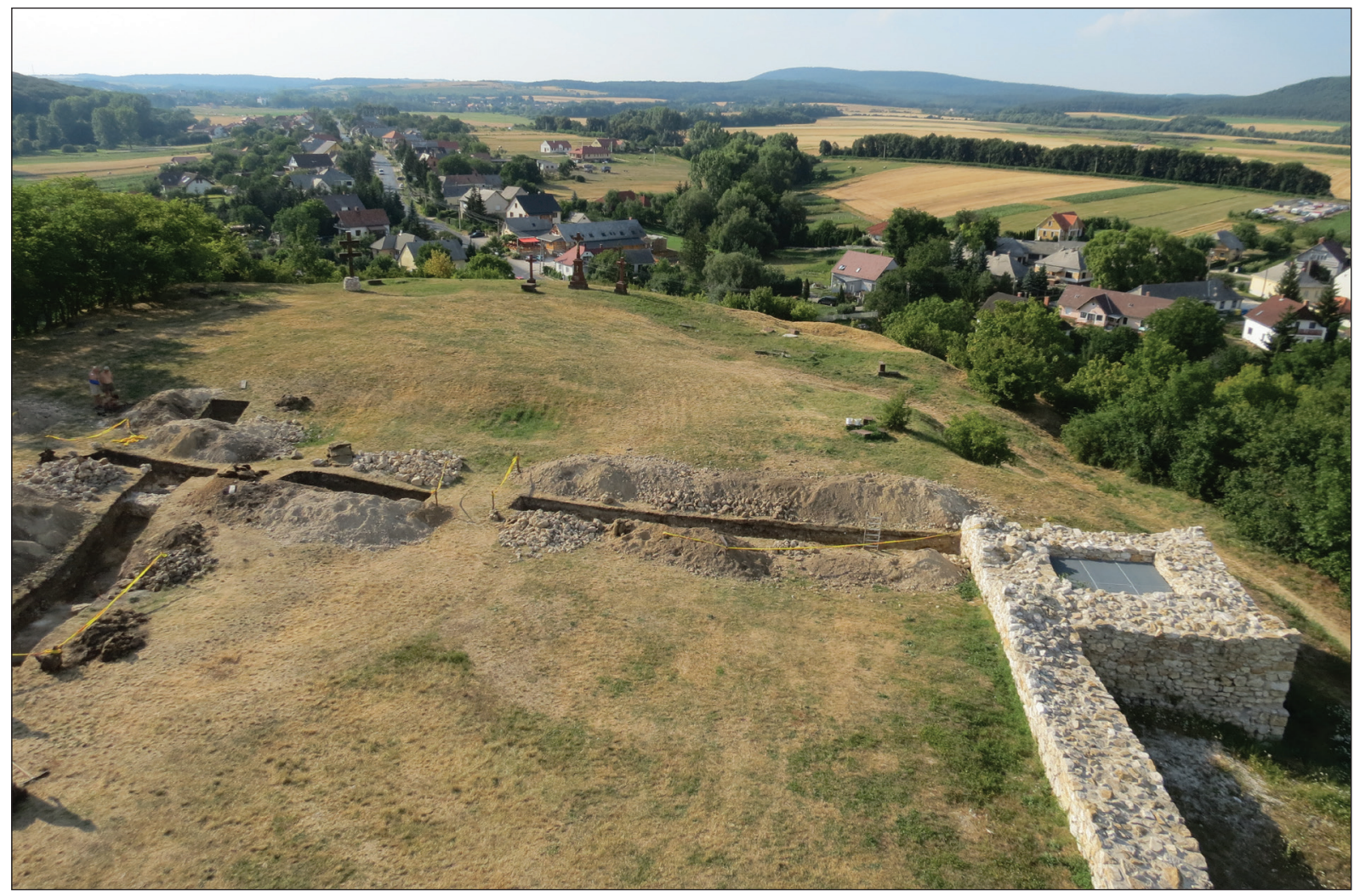

Fig. 2. Bird's-eye view from the tower with the trenches of 2013 (Photo: Sz. B. Nagy).

Beside the descendants of Lőrinte the aforementioned Nicholas magister also appears as possessor of the castle in the charters of 1327 and 1332. The property division of 1341 preserve some highly relevant pieces of information about the castle and its surroundings. The eastern part of the castrum was assigned to Nicholas and his sons, while the western part was divided among the mentioned Thomas's heirs. In the southern quarter of the western part a (presumably) brick tower ("turris tegularis") was mentioned, while in the northern quarter a palace ("pallatium") stood. The partition charter speaks about some lower castle as well as a bigger 
gate ("porta maior"). The kinsfolk also agreed on two mills in the village, a quarry and lime kiln at the foot of the castle hill and the place of an old granary. There is no hint of a village church, the first evidence for which survived in the register of the papal tithes of 1333-1335. This invaluable source mentions priest Gregory of Bánd parish and Michael of "Sing". ${ }^{3}$ In light of the recent excavations - as will be demonstrated - the issue of identifying this "Sing" might be particularly interesting, although its resolution will need further inquiries.

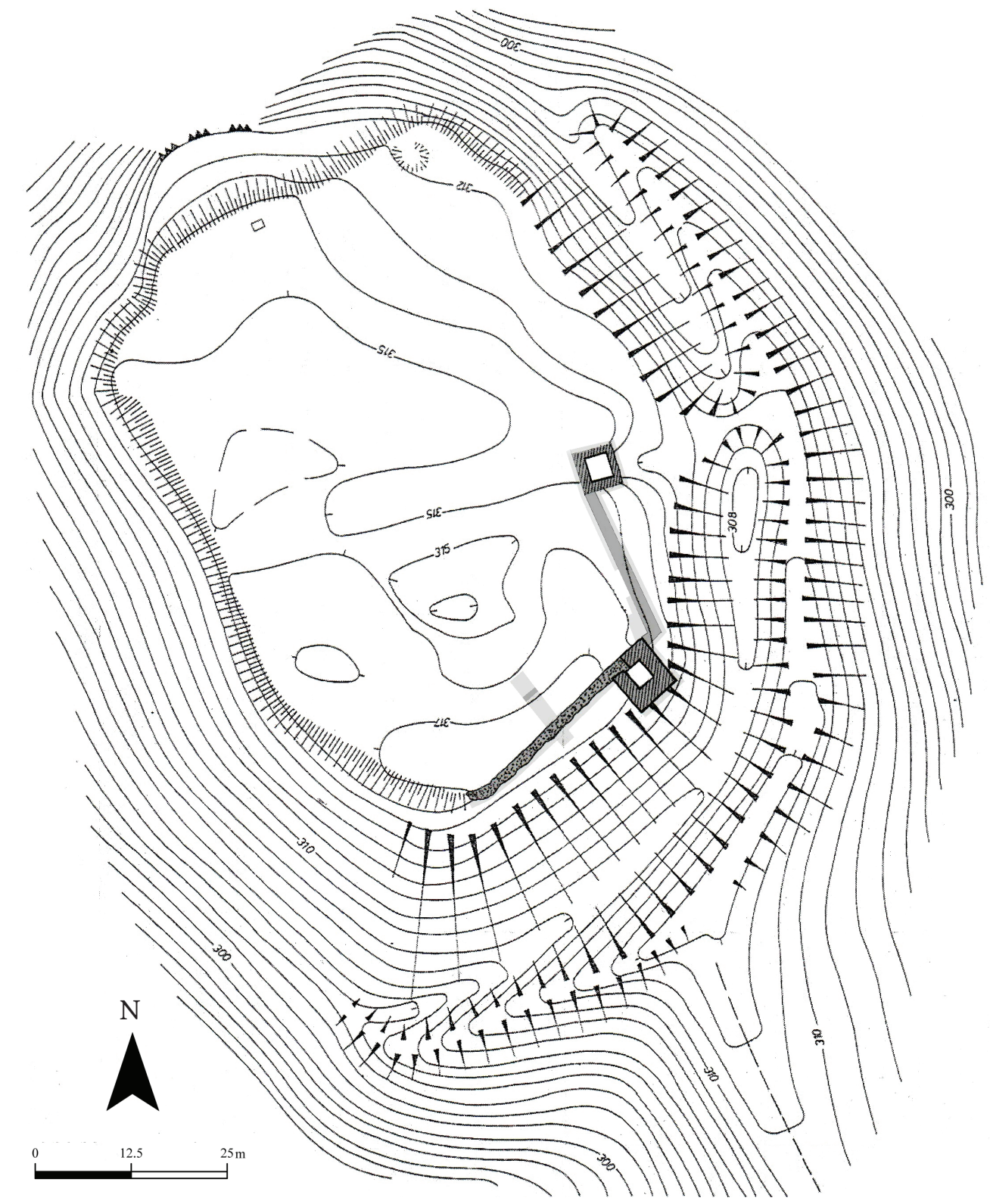

Fig. 3. Excavations of 1997-2007. Dark grey: unearthed walls; light grey: trenches. (After the survey of Gy. Nováki).

Throughout the fourteenth century the Essegvári family belonged to the better-off stratum of the lesser nobility, slightly beneath the levels of major lords and aristocrats of the kingdom. However, the death of John Essegvári around 1390 without male heirs has called forth a turning point in the history of both the family and its fortification. Terminating a long litigation 
between the family and the kinsfolk King Sigismund of Luxemburg (1387-1437) has seized the castle and appointed Stephen Rozgonyi as royal castellan of Essegvár before 1410. Until 1439 at least the castle was held by the Rozgonyi family, although some estates attached to it may have been possessed by the Essegvári. ${ }^{4}$

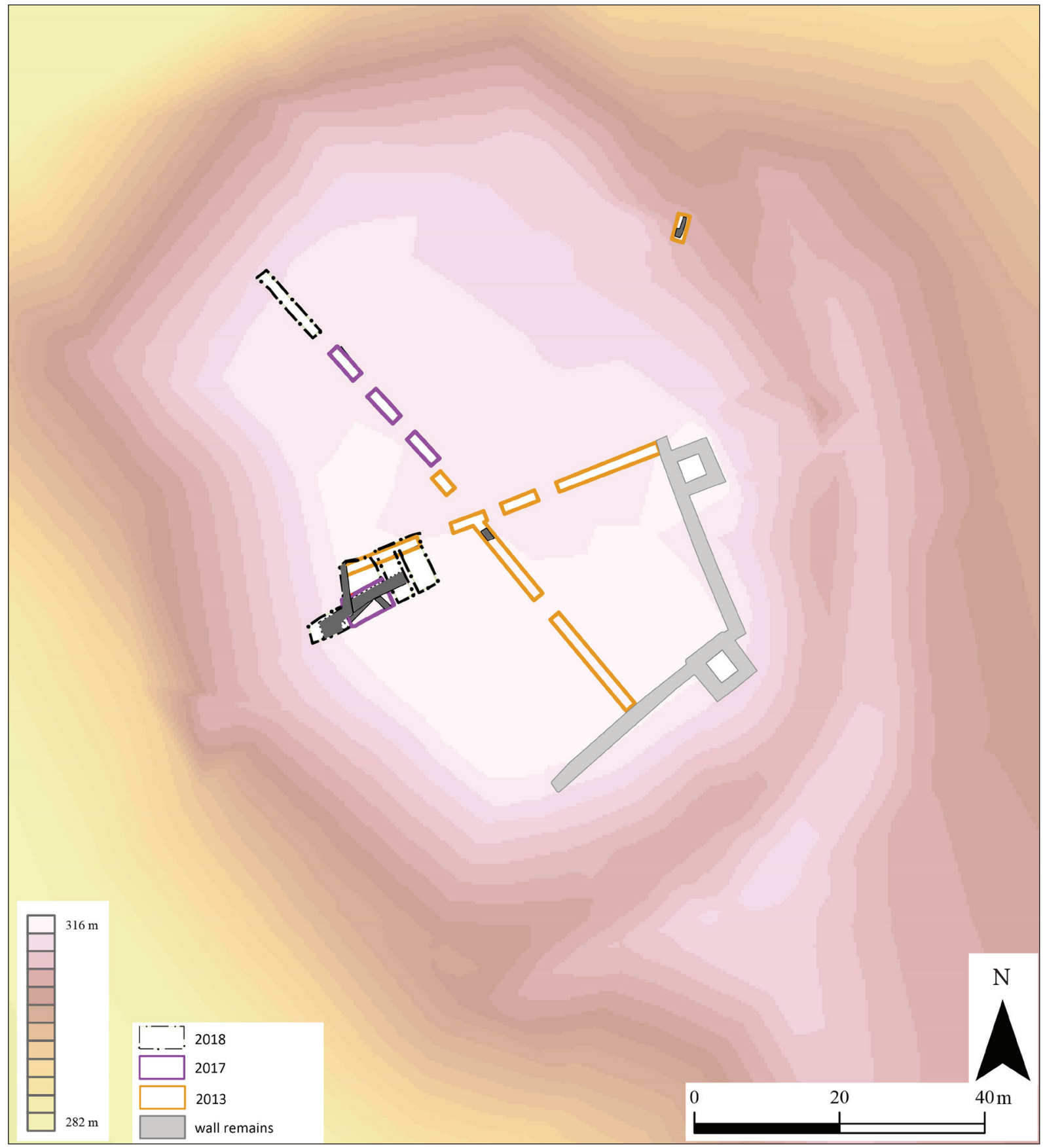

Fig. 4. Excavation plan of 2013-2018 (Sz. B. Nagy).

Small wonder that the latter has done its utmost to reseize its one and only castle that had lent its name to them. Written records testify that Essegvár was actually held by Paul Essegvári in 1440 as well as in 1445. Meanwhile - in the turbulent years of the civil war of 1439-1445 - serious negotiations have opened over the castle between the branches of the Rozgonyi family, 


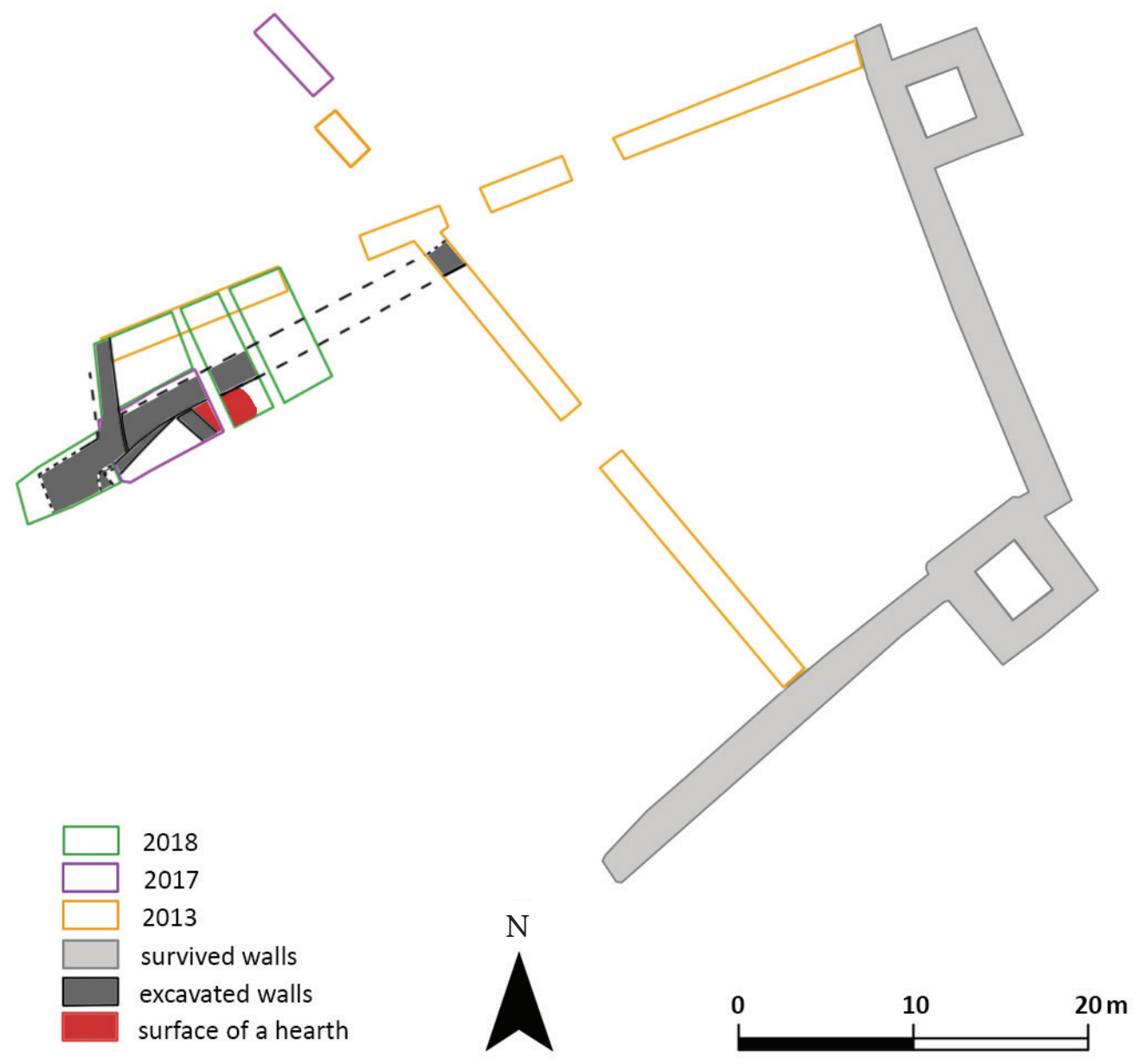

Fig. 5. Detail of the excavation plan (Sz. B. Nagy).

moreover, the highly powerful baron Nicholas Ujlaki has also claimed and probably taken the castle. During the reign of Matthias Corvinus (1458-1490) the Rozgonyis have gradually lost ground and the castle has been divided between the Ujlakis and the Essegváris in - theoretically - equal shares. This partition survived until 1507, although the dual ownership must have presented great difficulties and tensions. There are reasons to assume that the Essegvári family which - still belonging to the well-endowed lesser nobility - had taken service with the great landowner magnate Ujlaki family was not able to enforce the entirety of its rights in the castle. For instance, a charter of 1477 narrates that Lawrence Ujlaki had excluded George Essegvári from the fortification. This source also speaks about an archaeologically undetected Saint George chapel ("capella Beati Georgii martiris") standing in the western part of the castle. ${ }^{5}$

The unequal relationship between the Ujlakis and Essegváris may have also contributed to the decision of the latter to move their residence from Essegvár to Csékút in the first half of the 1490s. Finally, the situation was settled by a fortunate matrimony around 1499-1500. Francis Essegvári, son of George Essegvári married the one and only heiress of Emeric Himfi of Döbrönte by which - after the death of Emeric around 1501-1502 - he also inherited the eponym castle of Döbrönte which became the new residence of the family. The significance of the ancient seigneurial seat has started to decline, perhaps especially after 1507 when Lawrence Ujlaki donated his share to the chapter of Veszprém. According mainly to its topography with

5 Horváth 2002, 17-26, 31-32; RAINER 2008, 28-34. 
the adjacent hills and elevations, the small fortification had no real military value in the face of the Ottoman advance, and was most probably abandoned after the fall of Veszprém in 1552. It was referred to as ruinous already in 1586, when the Essegvári family became extinct. ${ }^{6}$

\section{Excavations in Essegvár}

Apart from minor field walks archaeological investigations of the site began not earlier than the very last years of the twentieth century. Since the excavations of 1997, 2005, 2006 and 2007 have already been summarized by the leader of these works, Pál Rainer, I only mention some of his results by chance. ${ }^{7}$ Research was reopened by István Feld in 2013 with the assistance of Dóra Hegyi and Szabolcs Balázs Nagy. ${ }^{8}$ The main purpose of working in narrow long east-west and north-south trenches was to gain essential pieces of information about the archaeological layers and preserved architectural remains under surface, and hence elaborating a research strategy. During 2017-2018, these original inquiries have been accomplished by reaching the steep northern hillside, and an interesting western-southwestern section of the castle - selected on the basis of our former results - has also been investigated (Figs 4-5). It is not surprising that at the present initial level of the research the number of emerging questions far exceeds the number of firm answers and conclusions. Resuming the results and hypotheses, however, seems to be justifiable, with special regard to the latest striking observations concerning the early history of the castle.

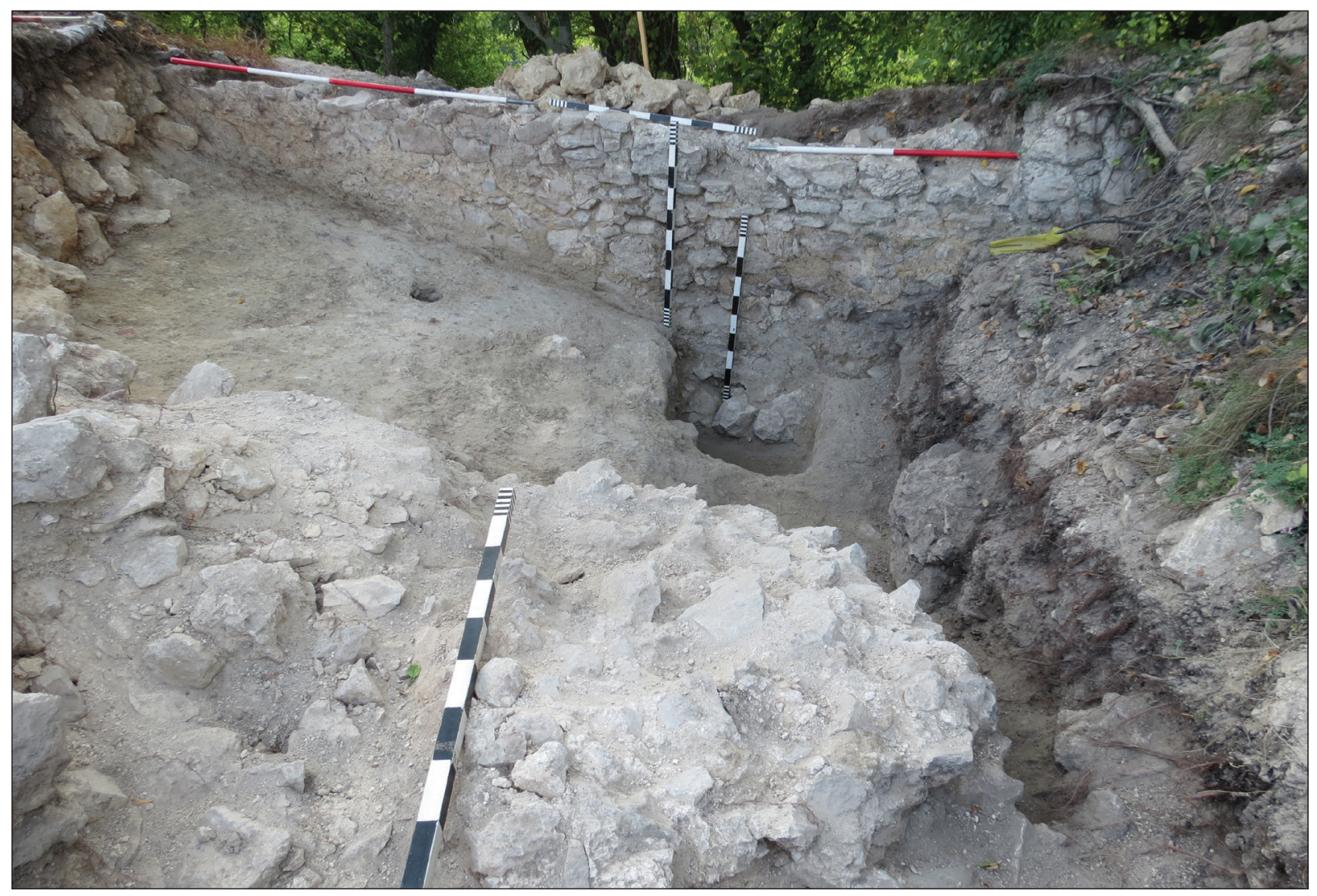

Fig. 6. Detail of the dividing ditch and the castle wall (Photo: Sz. B. Nagy). 


\section{Layout and buildings of Essegvár}

Perhaps the most surprising discovery of 2013 was the almost unified stratigraphic sequence of layers in the east-west excavation trench. The northward inclination of the thin brownish layer directly covering the natural rock surface; the thick debris layer of stones and mortar upon the thin brownish layer; and further observations in the north-south excavation trench all implied that the castle was divided by a wide east-west ditch in the Middle Ages (Fig. 6). A stone wall was built on the southern bank of the artificial ditch running parallel to it. Only humble remains have been detected of the wall in the north-south trench, however, significant crashed blocks could be identified in the debris layer filling the medieval ditch (Figs 7-8).

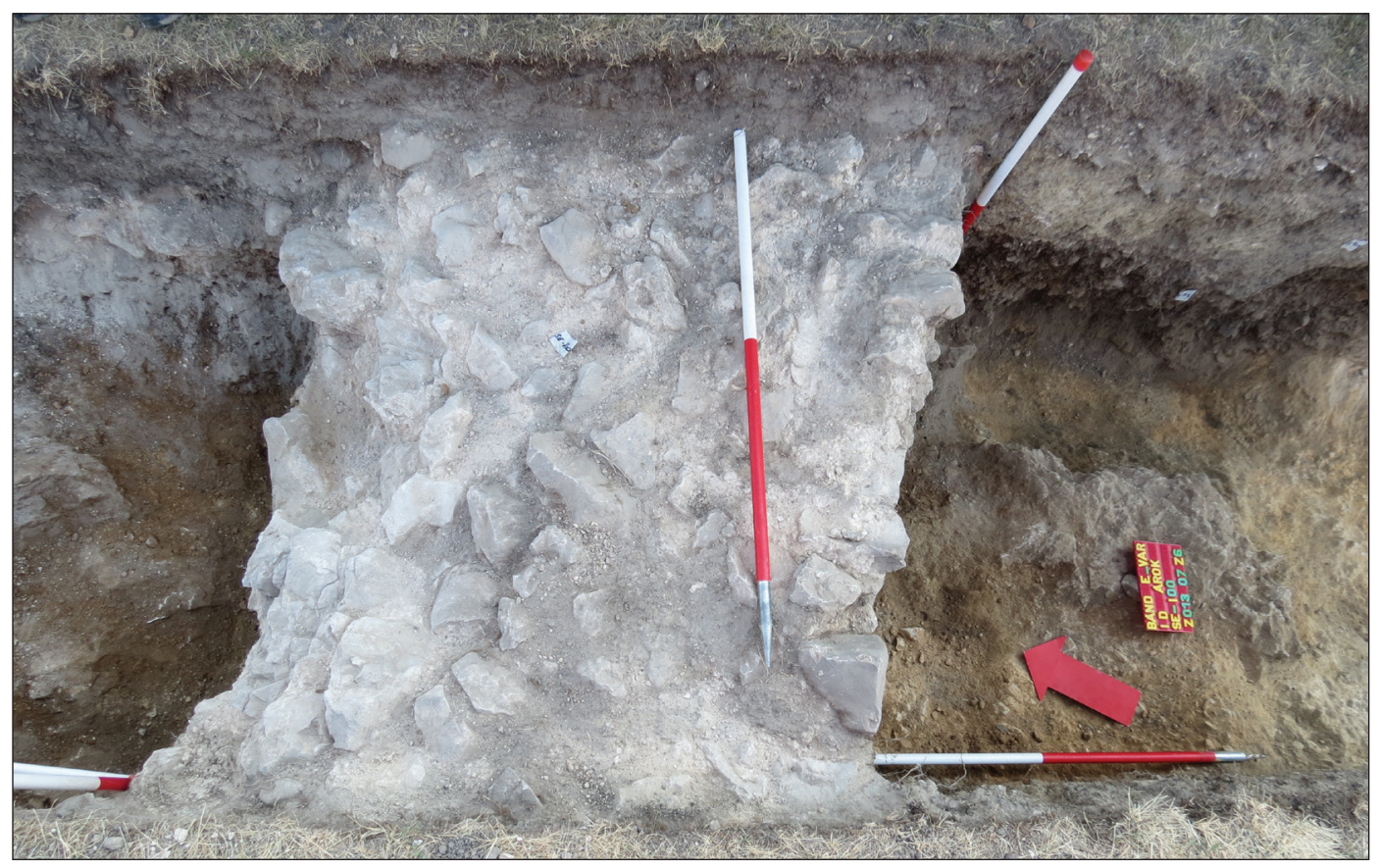

Fig. 7. Segment of the stone wall parallel to the ditch (Photo: Sz. B. Nagy).

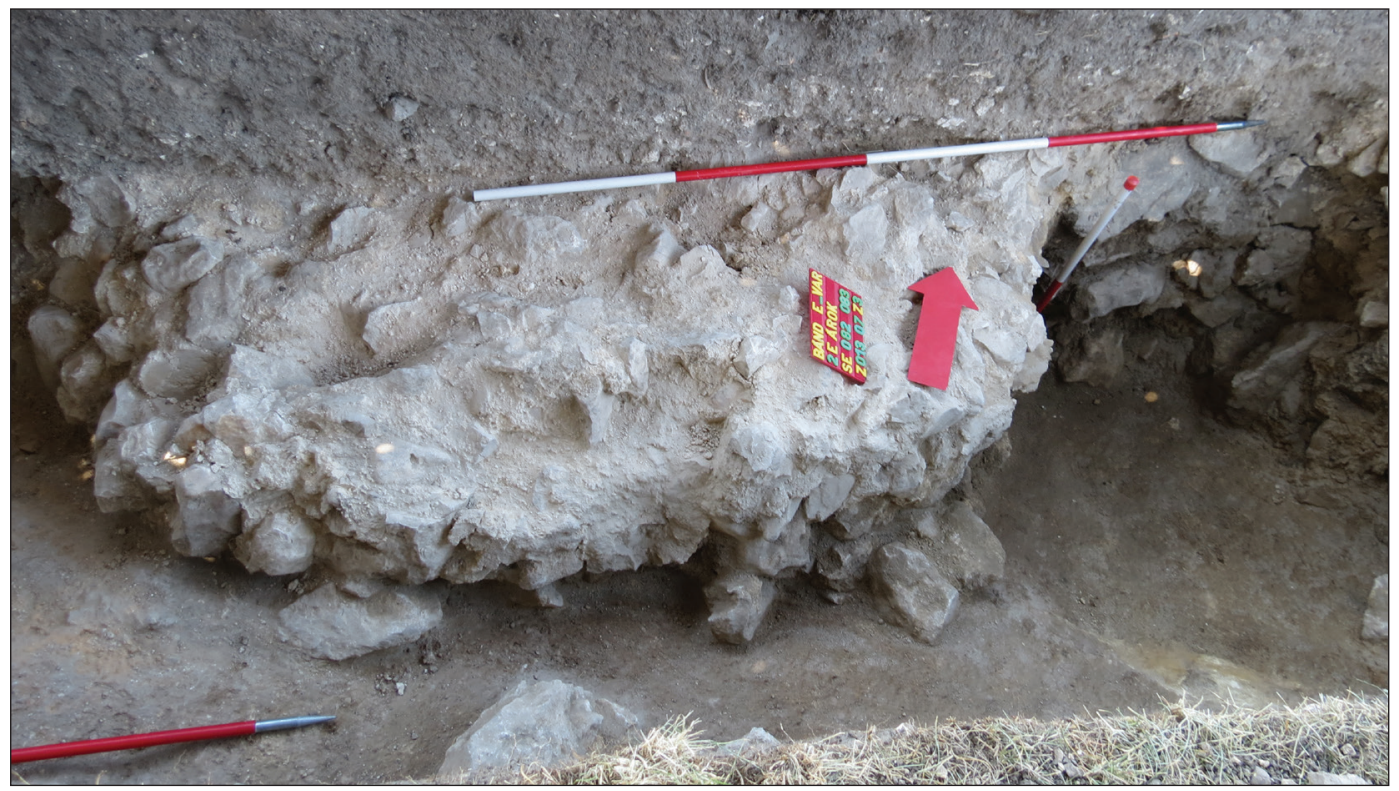

Fig. 8. Debris and a block of the crashed wall fallen into the ditch (Photo: Sz. B. Nagy). 
Latest excavations has confirmed our assumptions: both the ditch and the ca. 1.5 metre wide accompanying wall could be detected in the western-southwestern section. The remains demonstrated that the wall was attached to the outer castle wall that had been built on the edge of the castle hill. This latter stone wall - at its short unearthed section at least - was ca. 1.2 metre wide and, according to a few pot sherds, could have been erected during the fourteenth or the fifteenth centuries. No doubt this late medieval construction period must have changed the early (thirteenth-century?) layout of the castle fundamentally.

Observations have proven that the outer castle wall leading to south stopped at a certain point in our trench of 2017. This surprising characteristic could be explained only in 2018 when the unearthed section was extended to the west in the steep hillside. The huge stone building protruding the castle wall explored here can be interpreted as the remains of a square tower, built simultaneously with the castle wall (Figs 9-10). Its position fits well that of the eastern tower, although the trustworthy identification and dating is inconceivable without further investigations, since only a small segment is known of it for the present.

A 0.85 metre wide northwest-southeast wall resting on ca. $0.95 \mathrm{~m}$ wide foundations (unearthed also in 2017) suggests a stone building posterior to the described remains of the supposed tower. The width of the wall and the different layers and levels on the two sides of it imply a cellared, presumably storeyed building. Its wall was attached at an angle of $70^{\circ}$ to the east-west dividing wall that ran parallel to the medieval ditch (Figs 11-12). In the eastern corner of the two walls remains of a relatively large $(2.7 \times 2$ metre at least $)$ surface of a hearth was found (Fig. 13). The hearth was renewed at least once and both of its pre-

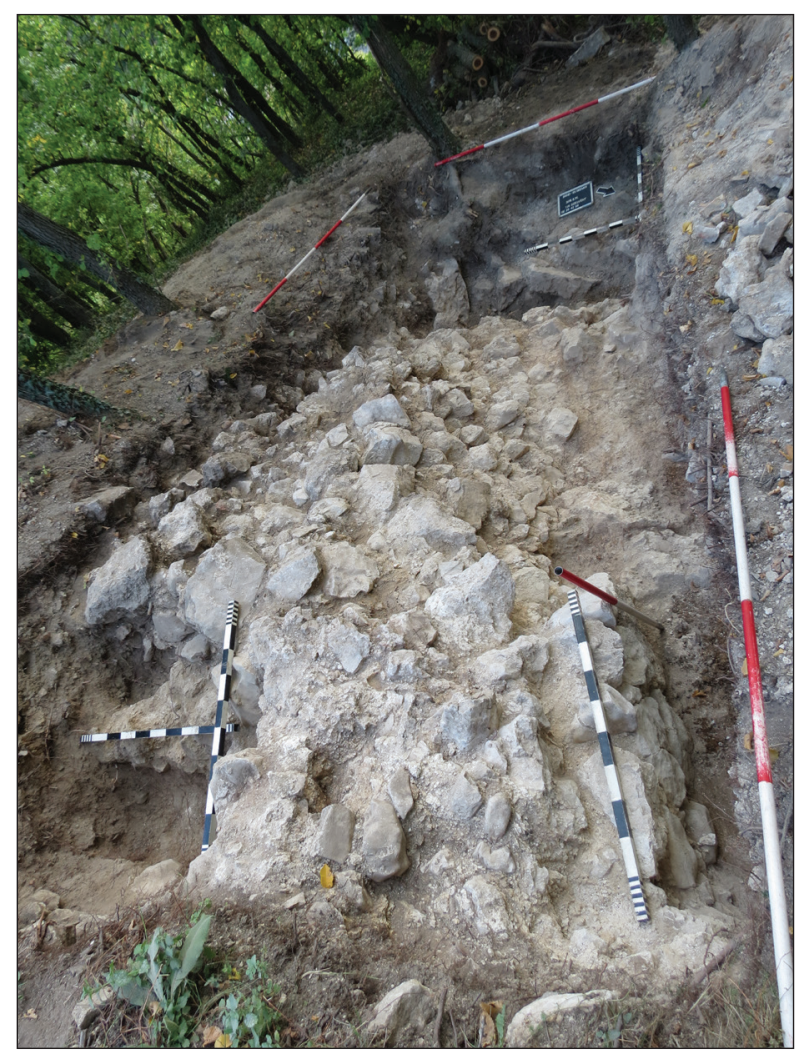

Fig. 9. Remains of a protruding tower(?) on the steep western slope of the castle hill (Photo: G. Szoboszlay).

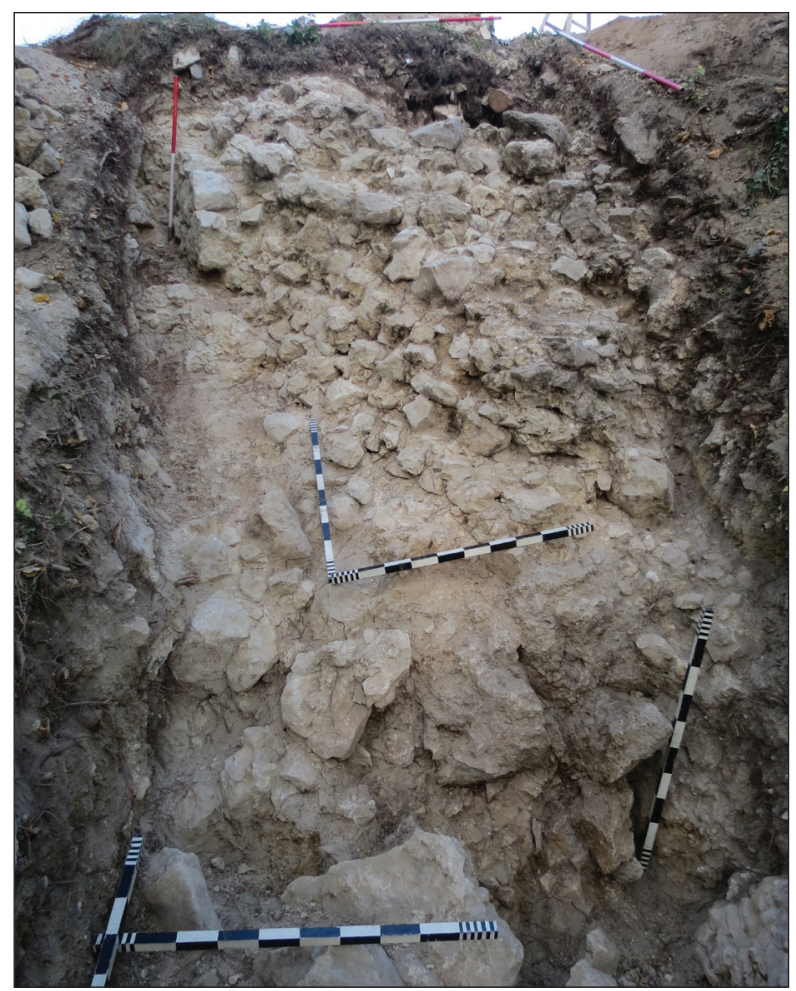

Fig. 10. The tower(?) from the west (Photo: G. Szoboszlay). 


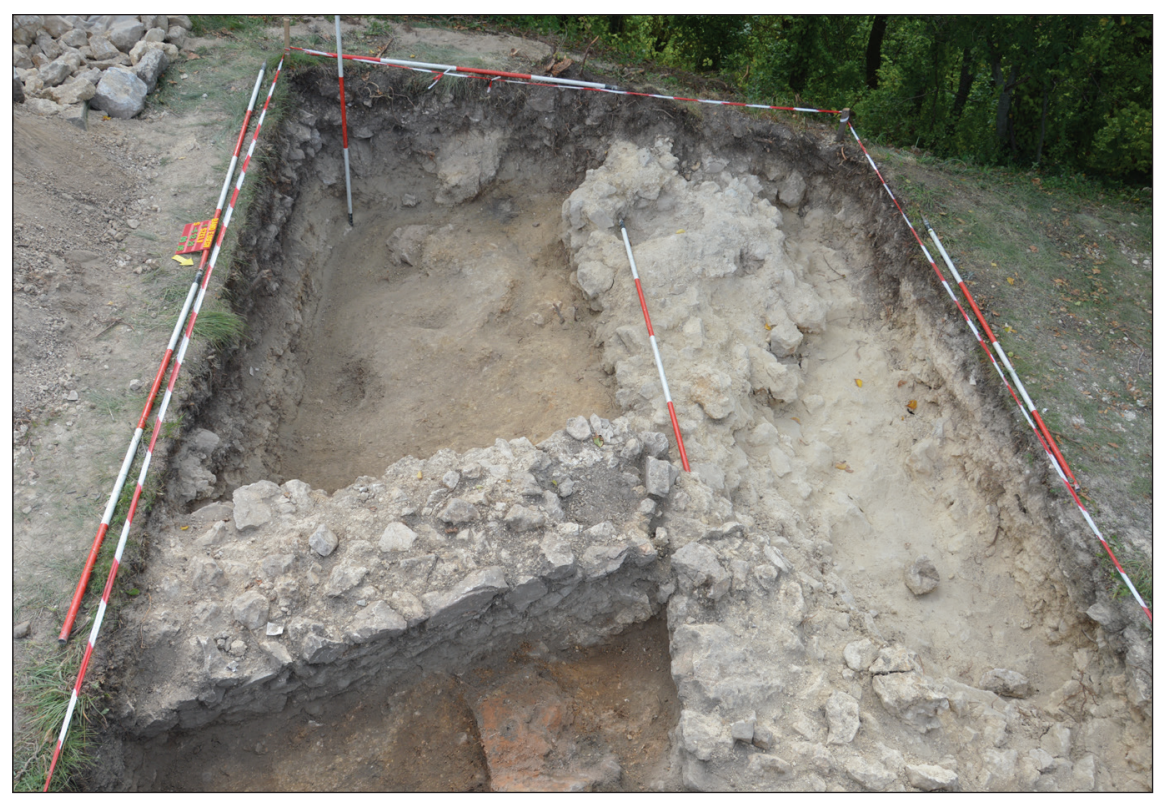

Fig. 11. Segment of the cellared building attached to the dividing wall (Photo: Sz. B. Nagy).

served surfaces were made of beaten clay, plastering several crashed ceramic pots and pebbles as well (Figs 14-15). Except for the fragmentary red surfaces the yellow clay standing walls or vaulting of the hearth have perished. Stratigraphy suggests that it was probably created shortly after that the cellared building had been built. Restoration works having been completed, coins uncovered from the surfaces as well as a glass in-

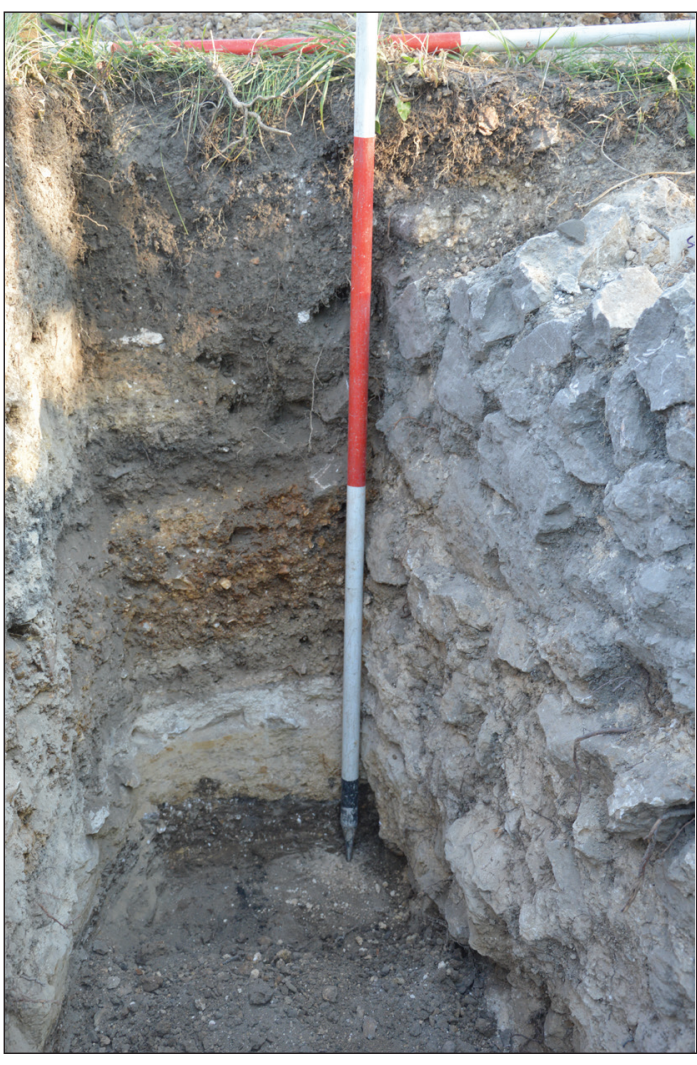

Fig. 12. Sequence of stratigraphic layers on the eastern side of the building (Photo: Sz. B. Nagy). laid ring found beneath them will provide (hopefully) a solid base concerning the establishment of the hearth and the adjacent building.

Instead of attempting a comprehensive interpretation of the remains, only a few assumptions can be sketched trustworthily. The cellared building stood in the northwestern angle of the southern part of the castle delimited from the north by a ditch and a stone wall. Presumably the building can be identified with a storeyed palace, while the large hearth in the corner could have served as an oven (indicating a kitchen?) for the catering of the inhabitants and personnel of the castle. Whether the oven stood inside a stone building, in the courtyard, or perhaps under the roof of a half open timber-framed space deserves further investigations. Parallel to the southern castle wall a small segment of another building has also come to light earlier. Judging from the $0.6 \mathrm{~m}$ width of the wall remain and its $4 \mathrm{~m}$ distance from the castle wall, a simple one-storied building can be assumed, presumably attached to the castle wall. 


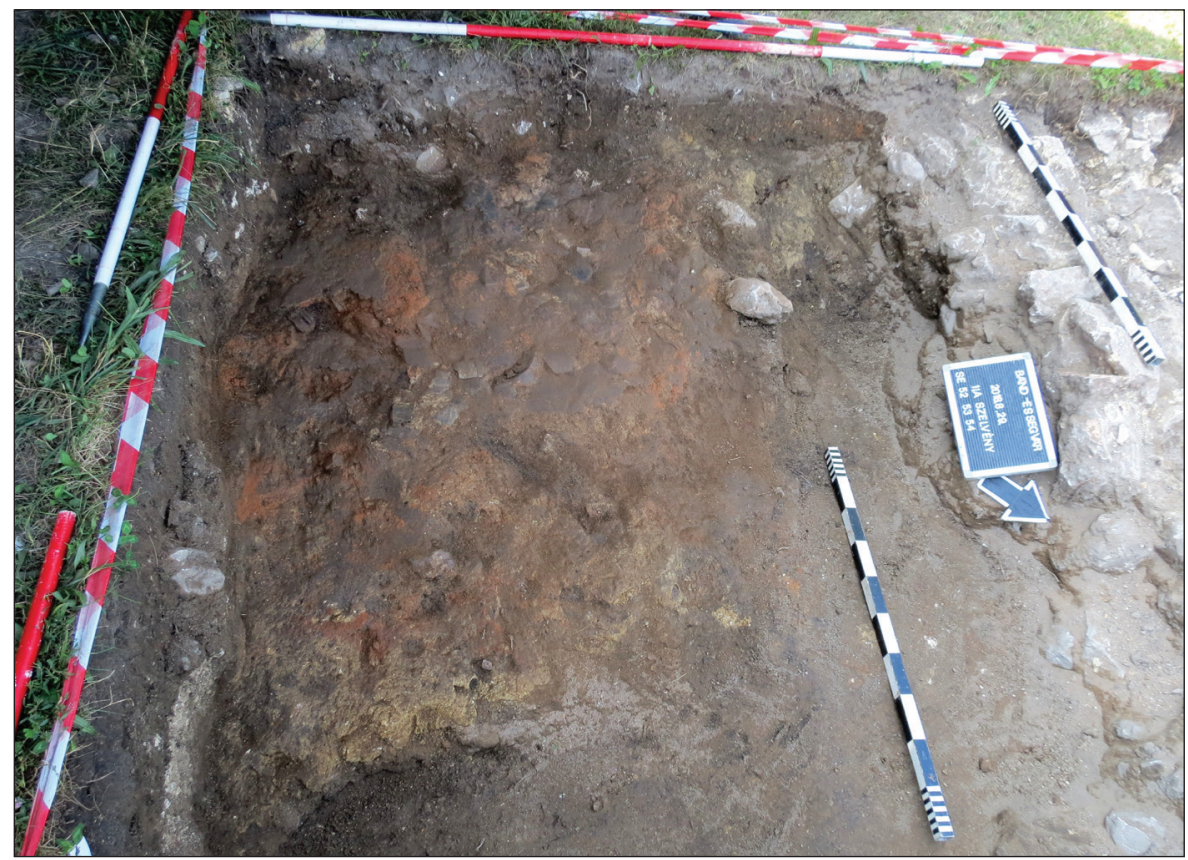

Fig. 13. Red surface of the large hearth (Photo: Sz. B. Nagy).

The buildings and late medieval use of the northern part of the castle is barely known. No traces of any walls or defenses could be detected in our north-south trenches and the lack of them is still an issue to be resolved. In any case, the wall remains unearthed in 2013 in the steep eastern hillside as well as the western castle wall crossing the artificial dividing ditch all confirm the obvious assumption that the northern part was also intergrated in the fortification. After the early modern devastations the ruins must have been used as a quarry for the local construction works and the remains (including the foundations and their trenches) were probably completely abolished. The observed filling layers and levels contained mainly late medieval finds, among others glazed ware and stove tile fragments as well as fifteenth-century coins. At first sight the human bone fragments also found here had presented a confusing surprise, however, the results soon explained their strange circumstances.

\section{A striking discovery: the early history of the castle hill}

At the bottom of Trench 2017/4 a highly compact fulvous layer of pebbles and rubble covered the natural dolomite surface of the hill. Despite meticulous soil stripping no traces of the grave contour could be identified of an undisturbed child grave (Fig. 16). The skeleton was on the back, oriented regularly west-east with the skull tilted towards the left, the right arm flexed over the chest, the left arm beside the waist and the legs slightly flexed and turned towards the left. The burial contained no furnishings or grave finds apart from a tiny iron rodlet found beside the skull directly next to the orbit. The identification of the poorly preserved find is unclarified, although perhaps its deposition can be linked to superstitious beliefs. In the same compact fulvous layer (but outside the presumable grave pit which had been cut in it) a few fragments of brick and stray fragments of further skeletons from completely disturbed burials have also been found. In a skull cleft in two three bronze S-shaped lock rings came to light.

A segment of a peculiar pit with irregular contour has been unearthed in the southeast corner of the same excavation trench (Fig. 17). The bottom of the pit was covered by a thin 


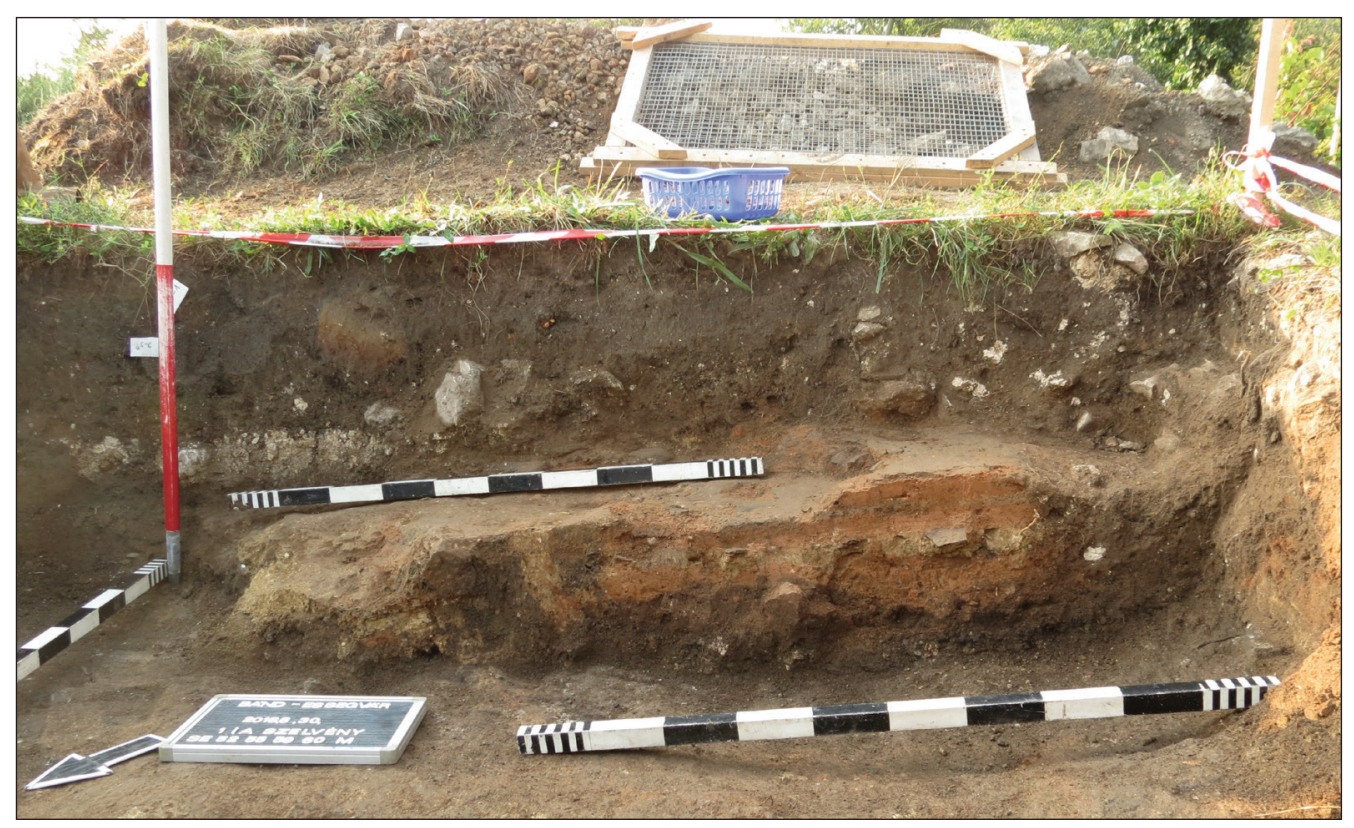

Fig. 14. Section of the plastered surfaces (Photo: Sz. B. Nagy).

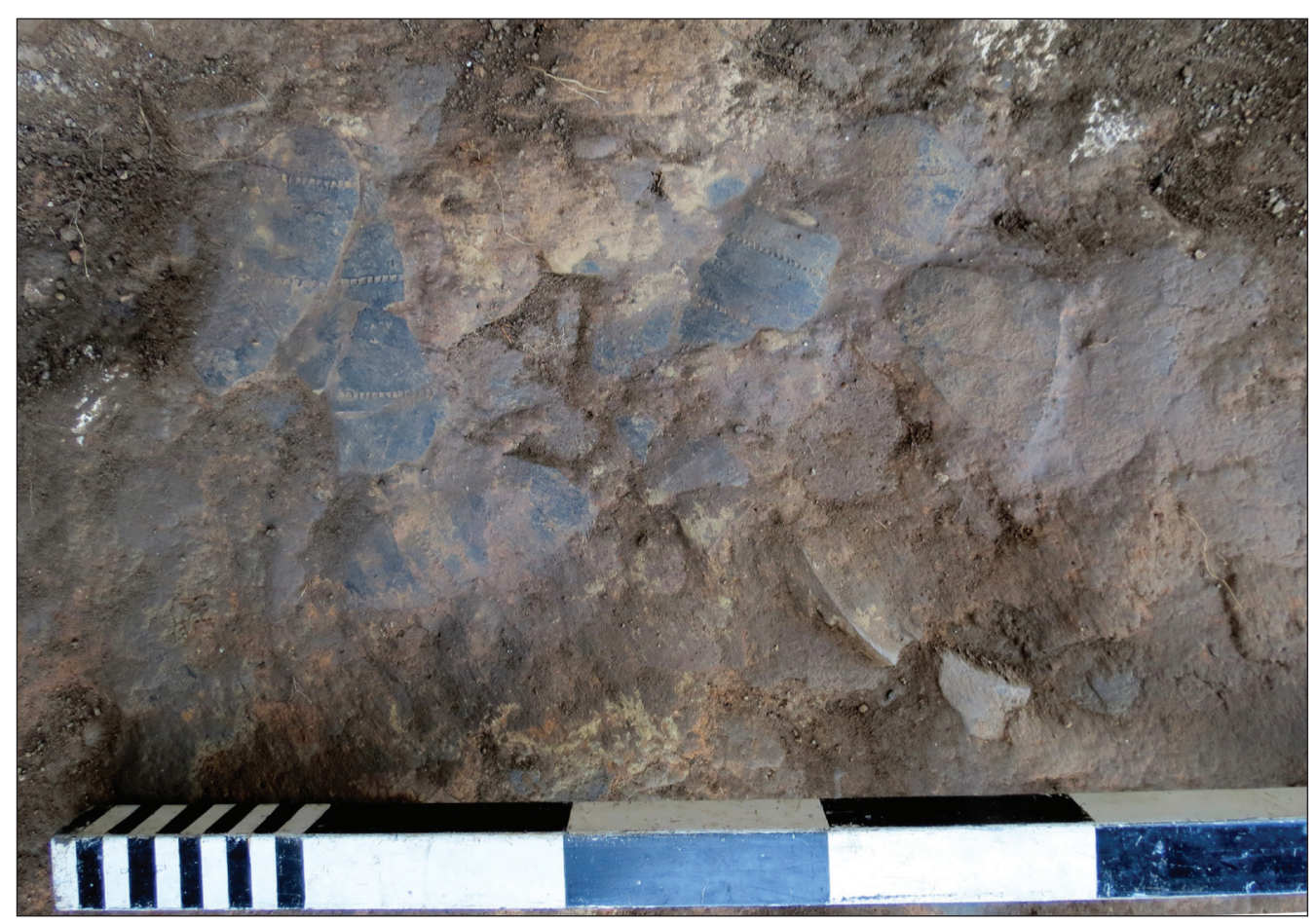

Fig. 15. Detail of a crashed vessel plastered in the surface (Photo: Sz. B. Nagy).

homogeneous lime layer while the fill contained a few charcoal layer and yielded typical Árpádian Age pot sherds, presumably from the eleventh-twelfth centuries. This pit was cut by an infant burial of which the eastern part outreached the trench and thus remained unexplored (Fig. 18). The undisturbed skeleton was similarly on the back, oriented west-east. Two fragments of a special brick (dimensions: $6 \times 10.5 \times$ ? $\mathrm{cm}$ ) were put in the grave behind the head, 5-8 cm west of the calvaria. Two coins of uncertain issuer from the twelfth century (one from the fill of the pit, one from either the fill of the pit or the infant grave) shed additional light on the problem of dating. 


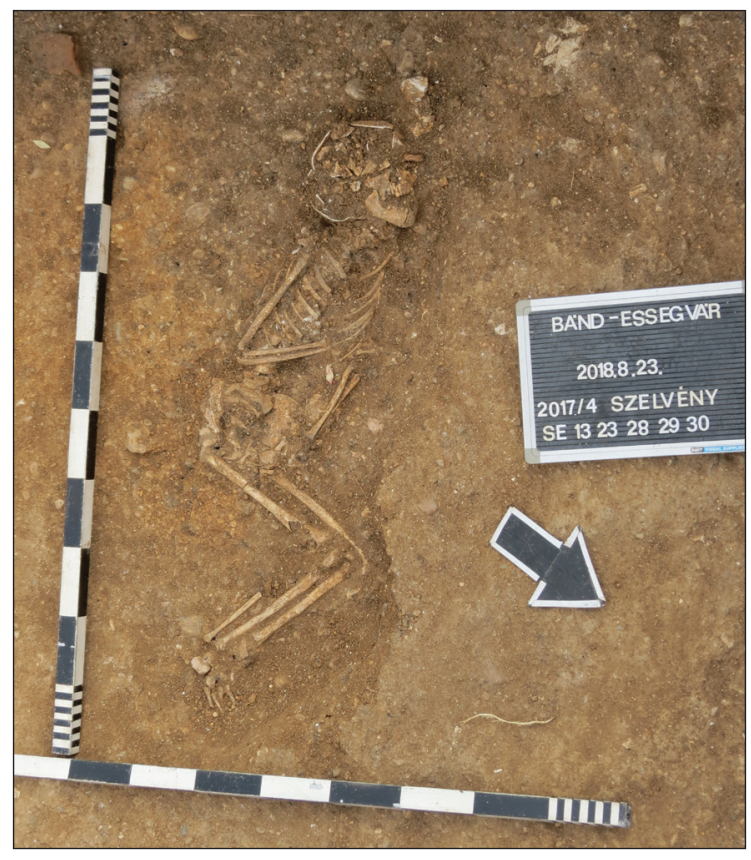

Fig. 16. Child's grave with atypical positioning of the skeleton (Photo: Sz. B. Nagy).

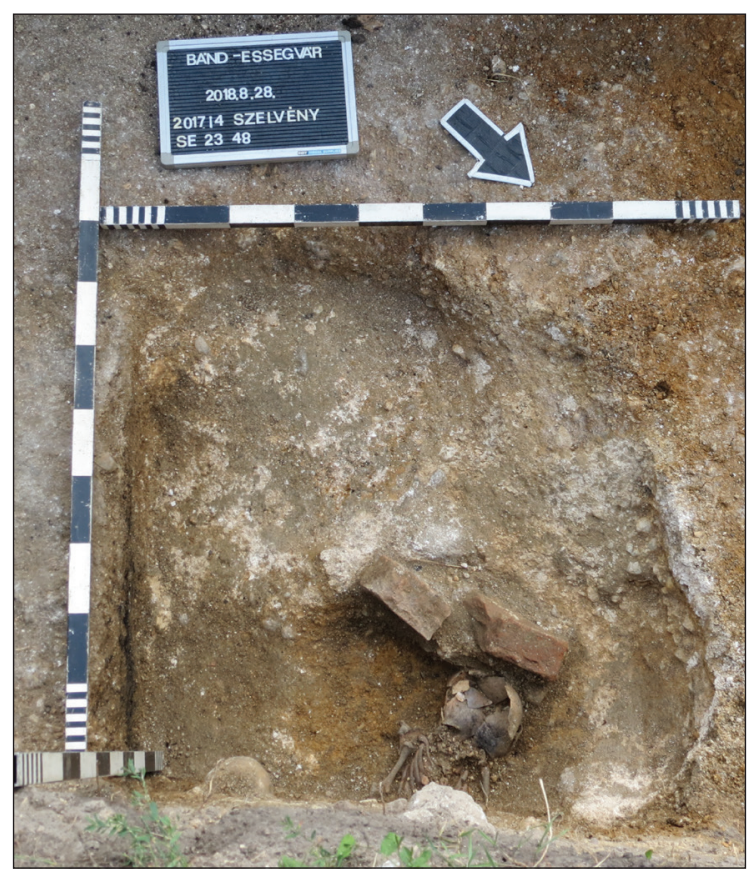

Fig. 17. Excavating the pit with limy bottom (Photo: Sz. B. Nagy).
Contours or details of some further burials (which have not yet been unearthed) were also identified in the trench. An adult burial occurred south of the infant grave and just below the limy bottom of the pit. This grave - similarly oriented west-east - must have been cut earlier than the pit. The top of two skulls also appeared between the described burials, probably indicating a deeper layer of graves (with hopefully undisturbed inhumations). Further investigations in and outside the trench will certainly yield many pieces of evidence about the cemetery. All in all, observations prove the existence of a multi-layered graveyard in the northern part of the castle hill established during the twelfth century at the latest. Its original extension and periods are temporarily obscure but it is highly probable that the burials gathered around an unknown chapel, assuming thus a typical Christian cemetery around a church.

\section{Competing cotenants? - Possible links between written and archae- ological evidence}

As already summarized, medieval written records mentioned a church or chapel at Bánd only twice: the fourteenth-century register of papal tithes (1333-1335) and the charter of 1477. The Saint George chapel of the latter erected in the western part of the castle held by George Essegvári is probably only a late establishment, judging from its patrocinium perhaps that of George Essegvári. In any case, there was no hint of a chapel in the division charter of 1341, despite the fact that the western part in question was described rather thoroughly. ${ }^{9}$ As to the papal tithes, it mentioned two churches, one of Bánd and one of "Sing". Older scholarship regarded Bánd as the predecessor of the present day village, while for "Sing" two interpretations were formulated identifying it either with Essegvár (i.e. the castle itself) or with a suburbium settlement called alternately "Seg" and "Váralja" (literally: [settlement] below the castle). ${ }^{10}$ 
However, the aforementioned charter of 1233 spoke about Bánd and "Seg" as interchangeable synonyms ("Seg sive Band"). Also the possessor family was alternately referred to by "Bándi" (literally: of Bánd) in a few cases during the mid-fourteenth century beside their usual noble predicatum Segvári and Essegvári. ${ }^{11}$ The correspondence of Bánd and the suburbium settlement is also confirmed by a charter of 1507 in which a settlement called "Warallya" (a variant for Váralja) appears as an appurtenant property of the castle endowed with customs right. ${ }^{12}$ Out of Essegvár Castle's appurtenant villages customs rights are known only at Bánd and Billege, therefore the mentioned "Warallya" suburbium must match to Bánd. On the whole, although the identification of the place names still lacks a solid base, it seems that the Bánd, "Seg"/"Sing" and "Váralja" denominations may have referred to the same settlement. Nevertheless, the village has probably consisted of different parts with different names and perhaps had more than one church. ${ }^{13}$

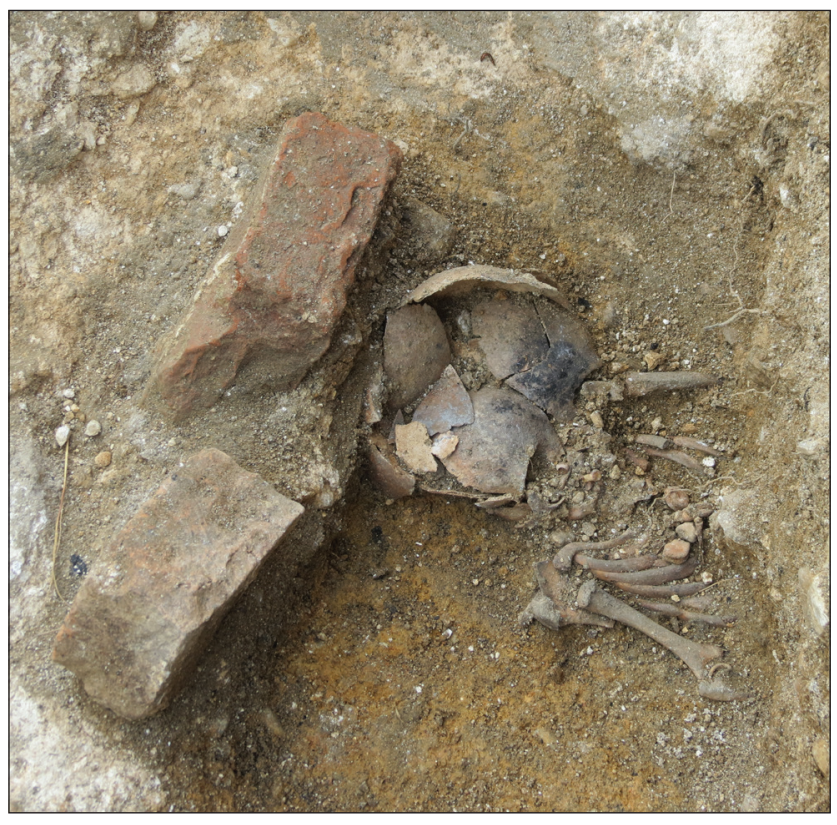

Fig. 18. Detail of the grave that cuts the pit (Photo: Sz. B. Nagy).
All in all, the cemetery and its presumable Árpádian Age church situated in the northern part of the castle hill cannot be linked trustworthily to the scarce data of the written sources. Further inquiries will be needed concerning the spatial and temporal relationships of the cemetery and the fortification as well. The twelfth-century finds suggest that the graveyard was established long before the erecting of the castle most probably in the second half of the thirteenth century. However, it is not impossible that preceeding the castle an early noble dwelling (a hypothetic manor house of which there is not a single piece of evidence yet) stood in the neighbourhood of the cemetery. A crucial issue is that whether or not the cemetery and the for-

tification were used concurrently for a few decades or even longer. Perhaps the explored artificial ditch and the parallel stone wall were constructed as a demarcation between the 'cotenants', i.e. the northern cemetery and the southern (early period) castle. Later the northern part was certainly incorporated in the fortification but the process of this transition seems to be an interesting change also from a historical point of view. Similar 'privati-

11 RAINER 2008, 17, 19.

12 RAINER 2008, 34.

13 The medieval topography of Bánd is barely known and therefore several further questions and aspects make the issue even more complex. The map of the so-called First Military Survey (1783-1786 in Hungary) indicates a ruin in the present day territory of the village north of the castle. It was hypothetically interpreted as the devastated medieval church of "Seg"/"Váralja" settlement. Farther off the castle to the southeast pot sherds were collected in the course of field walks which suggested the existence of a medieval village. This one was hypothetically identified with medieval Bánd, although no traces of its church have come to light so far. Moreover, an elevation called Várhegy (literally: castle hill) is located not far from the latter site, on the top of which medieval bricks were found and - allegedly - also subsurface wall remains of a pentagonal building were observed. See ÉRI et al. 1969, 64-66. 


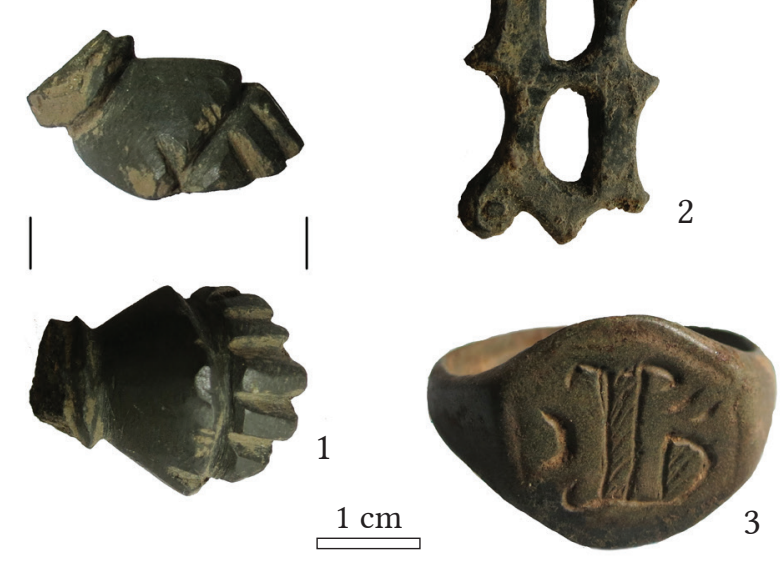

Fig. 19. 1-3 - selected bronze artefacts from the find assemblage (Photo: Sz. B. Nagy).

sation' of a church and the surrounding cemetery have been authenticated by archaeological research at a handful of sites in Hungary. Further investigations may clarify whether the graveyard was (gradually?) abandoned and the church was maintained as the cases of Kisnána Castle $^{14}$ and perhaps Várpalota Castle ${ }^{15}$ demonstrate, or the church was completely abolished according to the presumed building history of Ónod Castle. ${ }^{16}$

A different interpretation of the artificial ditch and wall can also be sketched in. The castle of Komlóska-Pusztavár was divided similarly by a ditch and stone wall into two, approximately equal parts. According to a charter from 1379 narrating the property division between the branches of the Tolcsva clan, this partition was cited as one of the possible reasons for the fortification's characteristic layout. ${ }^{17}$ Written evidence proves several fourteenth-fifteenth-century partitions and aims of partition also in Essegvár, even the conflicts of the dual ownership is testified. This historical background could also explain the unearthed ditch and wall, although written sources consistently mention an east-west partition, which seems to contradict the present archaeological evidence.

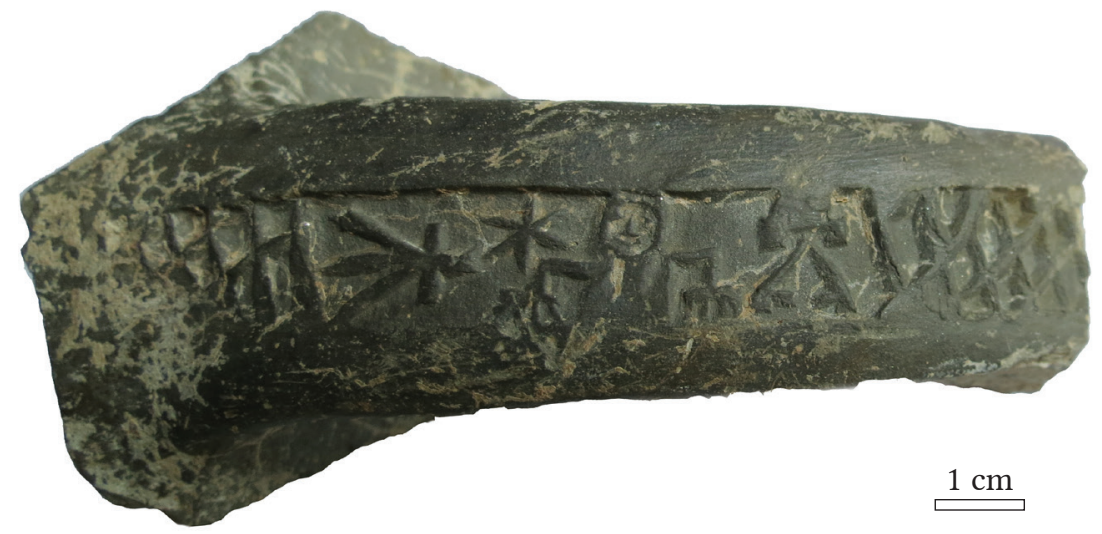

Fig. 20. Handle of a clay vessel with stamped figural decoration (Photo: Sz. B. Nagy).

\section{Some questions raised by the find assemblage}

Surprisingly, the overwhelming majority of small finds have been uncovered from the greyish humus layer directly below the grass. This humus covered large surfaces of the whole castle,

14 PÁmer 1970, 30-302, 306; VirÁgos 2006, 48-50; NAgy 2010; BuZÁs 2012, 2-4, 6-15, 21.

15 LÁszló 1992, 185; LÁsZLó 2006, 165.

16 Tомка 2000, 158, 160, 170-171; TOMKA 2018, 21, 25.

17 GÁl-Mlakár 2006, 13-14; GÁL-Mlakár 2007, and NovÁki et al. 2007 do not take sides concerning the reasons for dividing the castle. 

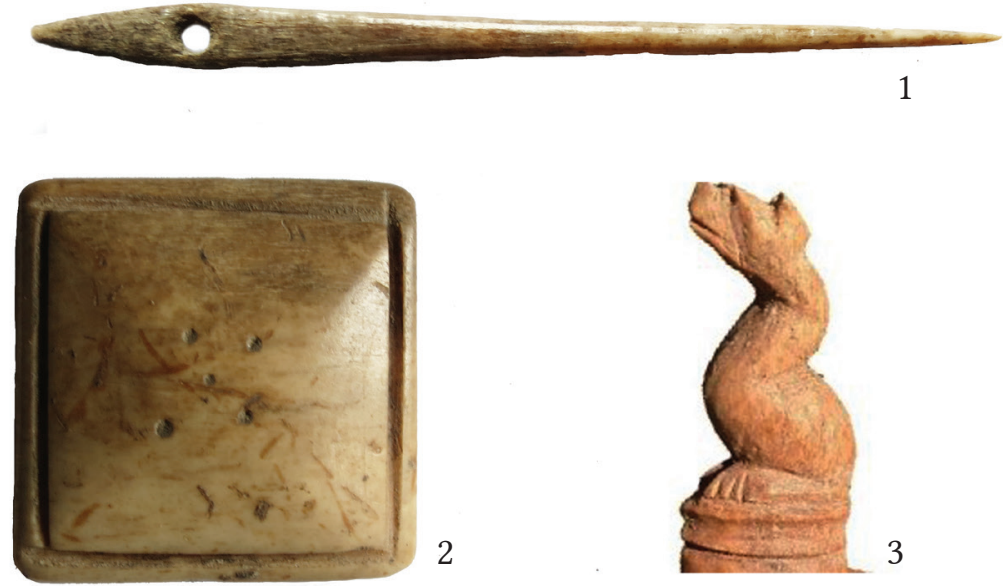

Fig. 21. 1-3 - selected bone and antler artefacts and their details (Photo: Sz. B. Nagy).

among others the debris layer filling the artificial dividing ditch and remains of the described clay plastered hearth. Coins found in the humus layer - coins of King Louis the Great of Anjou (1342-1382), King Sigismund of Luxemburg (1387-1437), King Albert I of Habsburg (14371439), King Wladislas I (1440-1444) and governor John Hunyadi (1446-1453) - imply that the layer was deposited or spread out around the mid-fifteenth century. A Late Roman crossbow brooch and a fragment of a vessel resembling the so-called pannonische Glanztonware-type were unexpected finds from the same layer. Despite these Roman artifacts, the finds were rather unified and characteristic of the material culture of a late medieval castle (Figs 19-21). One of the most interesting issues to be resolved by further investigations is the deposition of the humus layer: its reasons, way and exact time. It also needs to be clarified whether the spreading of the layer is contemporaneous with the finds uncovered in it or perhaps a rubbishy deposit (something like a waste-heap) containing great quantities of animal bones and pot sherds was carried and spread out on the surface of the fortification. In the former case, the conspicuous lack of sixteenth-century layers and finds can be explained by the modern disturbance as well as the twentieth-century landscaping and Calvary constructing executed on the castle hill.

\section{References}

BuzÁs, G. 2012: A kisnánai vár története. Archaeologia - Altum Castrum Online, 1-54.

ÉRI, I. - Kelemen, M. - Németh, P. - ToRMA, I. 1969: Veszprém megye régészeti topográfiája. A veszprémi járás. Magyarország Régészeti Topográfiája 2. Budapest.

GÁL-MlakÁR, V. 2006: Zemplén ismeretlen vára: a komlóskai Pusztavár. Várak, Kastélyok, Templomok. Történelmi és Örökségturisztikai Folyóirat II/6, 12-14.

GÁL-MLAKÁR, V. 2007: Komlóska-Pusztavár régészeti feltárásainak eredményei (Archaeological investigations at Komlóska-Pusztavár). A Herman Ottó Múzeum Évkönyve XLVI, 87-113.

Horváth, R. 2002: Várak és politika a középkori Veszprém megyében. PhD dissertation. Manuscript. Debrecen.

LÁszló, Cs. 1992: Újabb kutatások a várpalotai várban. In: CABello, J. (ed.): Castrum Bene 2/1990: Várak a késő középkorban. Budapest, 183-192.

LÁszló, Cs. 2006: A várpalotai 14. századi palota. In: Kovács, Gy. - MıкLós, Zs. (eds.): „Gondolják, látják az várnak nagy voltát...” Tanulmányok a 80 éves Nováki Gyula tiszteletére. Budapest, 163-170. 
Mordovin, M. 2013: Short report on the excavations in 2013 of the Department of Hungarian Medieval and Early Modern Archaeology (Eötvös Loránd University, Budapest). Dissertationes Archaeologicae 3/1, 153-178.

NaGy, Sz. B. 2010: A Kompoltiak temploma Kisnánán. Castrum 12, 5-42.

NAGy, Sz. B. 2014: Beszámoló Bánd-Essegvár 2013. évi régészeti kutatásáról. Castrum 17, 81-85.

NovÁKi, Gy. - SÁrкözy, S. - Feld, I. 2007: Borsod-Abaúj-Zemplén megye várai az őskortól a kuruc korig. Magyarország Várainak Topográfiája I. Budapest-Miskolc.

PÁmer, N. 1970: A kisnánai vár feltárása. Magyar Múemlékvédelem 1967-68, 295-313.

RAINER, P. 2008: Segvártól Essegvárig. A bándi vár és birtokosainak történetéből. Castrum 8, 7-47.

TomkA, G. 2000: Az ónodi vár. In: Veres, L. - Viga, Gy. (eds.): Ónod monográfiája. Ónod, 157-211.

ТомкA, G. 2018: 16-17. századi kerámia a történeti Borsod megyéböl (Early Modern Pottery in Northeastern Hungary). Opuscula Hungarica X. Budapest.

VirÁgos, G. 2006: The Social Archaeology of Residential Sites: Hungarian Noble Residences and their Social Context in the Thirteenth through to the Sixteenth Century. British Archaeological Report International Series 1583. Oxford.

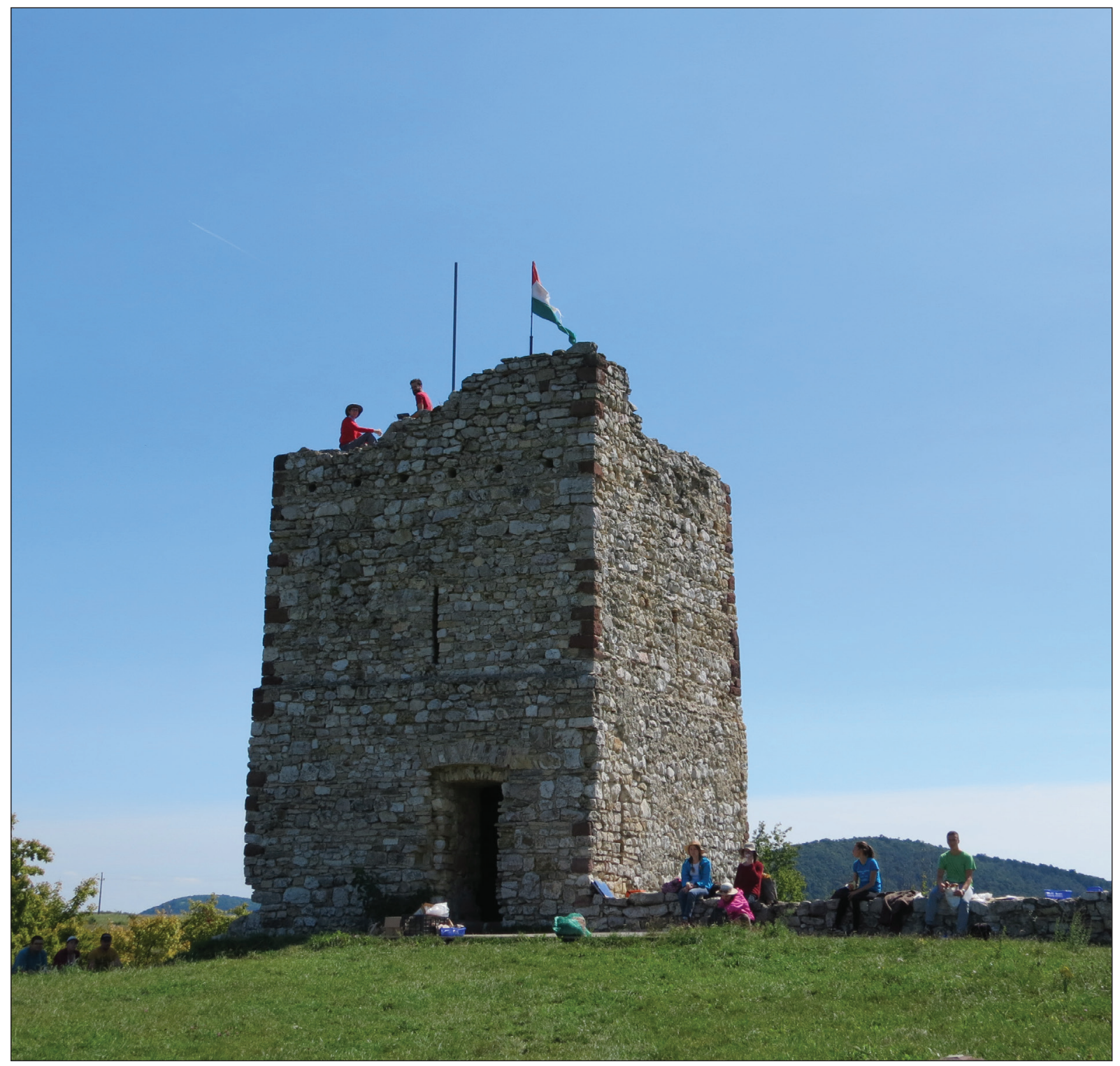

Fig. 22. The square tower during lunch break (Photo: Sz. B. Nagy). 